\title{
SINTAKSIS \\ (Komponen dan Struktur)
}

\author{
Surianti Nafinuddin \\ suriantiunismuh123@gmail.com
}

\begin{abstract}
Abstrak
Urutan hierarki satuan-satuan linguistik bahwa satuan yang satu tingkat lebih kecil akan membentuk satuan yang lebih besar yaitu : wacana, kalimat, klausa, frase, kata, morfem, fonem. Urutan hierarki tersebut adalah urutan normal teoritis. Dalam praktek berbahasa banyak faktor yang menyebabkan terjadinya penyimpangan urutan. Kalau dalam urutan normal kenaikan tingkat atau penurunan tingkat terjadi pada jenjang berikutnya yang satu tingkat ke atas atau satu tingkat ke bawah, maka dalam pelompatan tingkat terjadi peristiwa, sebuah satuan menjadi konstituen dalam jenjang, sekurang-kurangnya, dua tingkat di atasnya. Kasus pelapisan tingkat terjadi kalau sebuah konstituen menjadi unsur konstituen pada konstruksi yang tingkatannya sama. Dan kasus penurunan tingkat terjadi apabila sebuah konstituen menjadi unsur konstituen lain yang tingkatannya lebih rendah sari tingkatan konstituen asalnya.
\end{abstract}

Keyword: sintaksis, jenis, kata, frase, kalimat, wacana

\begin{abstract}
The hierarchical order of linguistic units that one level smaller will form a larger unit, namely: discourse, sentence, clause, phrase, word, morpheme, phoneme. The hierarchy is theoretically normal. In language practice there are many factors that cause deviations in the order. If in the normal sequence the level increase or decrease in the level occurs at the next level which is one level up or one level down, then in a level jump event occurs, a unit becomes a constituent in the level, at least, two levels above it. A case of level coating occurs when a constituent becomes a constituent element in the same level construction. And the case of a decrease in the level occurs when a constituent becomes another constituent element whose level is lower than the original constituent level.
\end{abstract}

Keyword: syntax, type, word, phrase, sentence, discourse 


\section{Pengertian Sintaksis}

Kata sintaksis berasal dari bahasa Yunani, yaitu sun yang berarti "dengan" dan kata tattein yang berarti "menempatkan". Jadi, secara etimologi berarti: menempatkan bersama-sama kata-kata menjadi kelompok kata atau kalimat.

\section{Struktur Sintaksis}

Secara umum struktur sintaksis terdiri dari susunan subjek (S), predikat (P), objek (O), dan keterangan (K) yang berkenaan dengan fungsi sintaksis. Nomina, verba, ajektifa, dan numeralia berkenaan dengan kategori sintaksis. Sedangkan pelaku, penderita, dan penerima berkenaan dengan peran sintaksis. Eksistensi struktur sintaksis terkecil ditopang oleh urutan kata, bentuk kata, dan intonasi; bisa juga ditambah dengan konektor yang biasanya disebut konjungsi. Peran ketiga alat sintaksis itu tidak sama antara bahasa yang satu dengan yang lain.

\section{Satuan Sintaksis}

\section{Kata}

Sebagai satuan terkecil dalam sintaksis, kata berperan sebagai pengisi fungsi sintaksis, penanda kategori sintaksis, dan perangkai dalam penyatuan satuan-satuan atau bagian-bagian dari satuan sintaksis.

Kata sebagai pengisi satuan sintaksis, harus dibedakan adanya dua macam kata yaitu kata penuh dan kata tugas. Kata penuh adalah kata yang secara leksikal mempunyai makna, mempunyai kemungkinan untuk mengalami proses morfologi, merupakan kelas terbuka, dan dapat berdiri sendiri sebagai sebuah satuan. Yang termasuk kata penuh adalah kata-kata kategori nomina, verba, adjektiva, adverbia, dan numeralia. Misalnya mesjid memiliki makna 'tempat ibadah orang Islam '. Sedangkan kata tugas adalah kata yang secara leksikal tidak mempunyai makna, tidak mengalami proses morfologi, merupakan kelas tertutup, dan di dalam peraturan dia tidak dapat berdiri sendiri. Yang termasuk kata tugas adalah katakata kategori preposisi dan konjungsi. Misalnya dan tidak mempunyai makna leksikal, tetapi mempunyai tugas sintaksis untuk menggabungkan menambah dua buah konstituen.

Kata-kata yang termasuk kata penuh mempunyai kebebasan yang mutlak, atau hampir mutlak sehingga dapat menjadi pengisi fungsi-fungsi sintaksis. Sedangkan kata tugas mempunyai kebebasan yang terbatas, selalu terikat dengan kata yang ada di belakangnya (untuk preposisi), atau yang berada di depannya (untuk posposisi), dan dengan kata-kata yang dirangkaikannya (untuk konjungsi).

\section{Frase}

a. Pengertian Frase

Frase lazim didefinisikan sebagai satuan gramatikal yang berupa gabungan kata yang bersifat nonpredikatif (hubungan antara kedua unsur yang membentuk frase tidak berstruktur subjek - predikat 
atau predikat - objek), atau lazim juga disebut gabungan kata yang mengisi salah satu fungsi sintaksis di dalam kalimat.

b. Jenis Frase

Adapun jenis-jenis frase adalah

\section{(1) Frase Eksosentrik}

Frase eksosentrik adalah frase yang komponen-komponennya tidak mempunyai perilaku sintaksis yang sama dengan keseluruhannya. Frase eksosentris biasanya dibedakan atas frase eksosentris yang direktif atau disebut frase preposisional ( komponen pertamanya berupa preposisi, seperti di, ke, dan dari, dan komponen keduanya berupa kata atau kelompok kata, yang biasanya berkategori nomina) dan non direktif (komponen pertamanya berupa artikulus, seperti si dan sang sedangkan komponen keduanya berupa kata atau kelompok kata berkategori nomina, ajektifa, atau verba).

\section{(2) Frase Endosentrik}

Frase Endosentrik adalah frase yang salah satu unsurnya atau komponennya memiliki perilaku sintaksias yang sama dengan keseluruhannya. Artinya, salah satu komponennya dapat menggantikan kedudukan keseluruhannya. Frase ini disebut juga frase modifikatif karena komponen keduanya, yaitu komponen yang bukan inti atau hulu (Inggris head) mengubah atau membatasi makna komponen inti atau hulunya itu. Selain itu disebut juga frase subordinatif karena salah satu komponennya, yaitu yang merupakan inti frase berlaku sebagai komponen atasan, sedangkan komponen lainnya, yaitu komponen yang membatasi, berlaku sebagai komponen bawahan.

Dilihat dari kategori intinya dibedakan adanya frase nominal (frase endosentrik yang intinya berupa nomina atau pronomina maka frase ini dapat menggantikan kedudukan kata nominal sebagai pengisi salah satu fungsi sintaksis), frase verbal (frase endosentrik yang intinya berupa kata verba, maka dapat menggantikan kedudukan kata verbal dalam sintaksis), frase ajektifa (frase edosentrik yang intinya berupa kata ajektiv), frase numeralia (frase endosentrik yang intinya berupa kata numeral).

\section{(3) Frase Koordinatif}

Frase koordinatif adalah frase yang komponen pembentuknya terdiri dari dua komponen atau lebih yang sama dan sederajat dan secara potensial dapat dihubungkan oleh konjungsi koordinatif. Frase koordinatif tidak menggunakan konjungsi secara eksplisit disebut frase parataksis.

\section{(4) Frase Apositif}

Frase apositif adalah frase koordinatif yang kedua komponennya saling merujuk sesamanya, oleh karena itu urutan komponennya dapat dipertukarkan.

Perluasan Frase 
Salah satu ciri frase adalah dapat diperluas. Artinya, frase dapat diberi tambahan komponen baru sesuai dengan konsep atau pengertian yang akan ditampilkan. Dalam bahasa Indonesia perluasan frase tampak sangat produktif. Antara lain karena pertama, untuk menyatakan konsep-konsep khusus, atau sangat khusus, atau sangat khusus sekali, biasanya diterangkan secara leksikal. Faktor kedua, bahwa pengungkapan konsep kala, modalitas, aspek, jenis, jumlah, ingkar, dan pembatas tidak dinyatakan dengan afiks seperti dalam bahasa-bahasa fleksi, melainkan dinyatakan dengan unsur leksikal. Dan faktor lainnya adalah keperluan untuk memberi deskripsi secara terperinci dalam suatu konsep, terutama untuk konsep nomina.

\section{Klausa}

\section{1) Pengertian Klausa}

Klausa adalah satuan sintaksis berupa runtunan kata-kata berkonstruksi predikatif. Artinya, di dalam konstruksi itu ada komponen, berupa kata atau frase, yang berungsi sebagai predikat; dan yang lain berfungsi sebagai subjek, objek, dan keterangan.

Klausa berpotensi untuk menjadi kalimat tunggal karena di dalamnya sudah ada fungsi sintaksis wajib, yaitu subjek dan predikat. Frase dan kata juga mempunyai potensi untuk menjadi kalimat kalau kepadanya diberi intonasi final; tetapi hanya sebagai kalimat minor, bukan kalimat mayor; sedangkan klausa berpotensi menjadi kalimat mayor.

\section{2) Jenis Klausa}

Berdasarkan strukturnya klausa dibedakan klausa bebas ( klausa yang mempunyai unsur-unsur lengkap, sekurang-kurangnya mempunyai subjek dan predikat; dan mempunyai potensi menjadi kalimat mayor) dan klausa terikat (klausa yang unsurnya tidak lengkap, mungkin hanya subjek saja, objek saja, atau keterangan saja). Klausa terikat diawali dengan konjungsi subordinatif dikenal dengan klausa subordinatif atau klausa bawahan, sedangkan klausa lain yang hadir dalam kalimat majemuk disebut klausa atasan atau klausa utama.

Berdasarkan kategori unsur segmental yang menjadi predikatnya dapat di bedakan: klausa verbal (klausa yang predikatnya berkategori verba). Sesuai dengan adanya tipe verba, dikenal adanya (1) klausa transitif (klausa yang predikatnya berupa verba transitif); (2) klausa intransitif (klausa yang predikatnya berupa verba intransitif); (3) klausa refleksif (klausa yang predikatnya berupa verba refleksif); (4) klausa resiprokal (klausa yang predikatnya berupa verba resiprokal. Klausa nominal (klausa yang predikatnya berupa nomina atau frase nominal). Klausa ajektifal (klausa yang predikatnya berkategori ajektifa, baik berupa kata maupun frase). Klausa adverbial (klausa yang predikatnya berupa frase yang berkategori preposisi). Klausa numeral (klausa yang predikatnya berupa kata atau frase numeralia). Perlu dicatat juga istilah klausa berpusat dan klausa tak berpusat. Klausa berpusat adalah klausa yang subjeknya terikat di dalam predikatnya, meskipun di tempat lain ada nomina atau frase nomina yang juga berlaku sebagai subjek.

\section{Kalimat}




\section{1) Pengertian Kalimat}

Dengan mengaitkan peran kalimat sebagai alat interaksi dan kelengkapan pesan atau isi yang akan disampaikan, kalimat didefinisikan sebagai "Susunan kata-kata yang teratur yang berisi pikiran yang lengkap ". Sedangkan dalam kaitannya dengan satuan-satuan sintaksis yang lebih kecil (kata, frase, dan klausa) bahwa kalimat adalah satuan sintaksis yang disusun dari konstituen dasar, yang biasanya berupa klausa, dilengkapi dengan konjungsi bila diperlukan, serta disertai dengan intonasi final.

Sehingga disimpulkan, bahwa yang penting atau yang menjadi dasar kalimat adalah konstituen dasar dan intonasi final, sedangkan konjungsi hanya ada kalau diperlukan. Intonasi final yang ada yang memberi ciri kalimat ada tiga, yaitu intonasi deklaratif, yang dalam bahasa tulis dilambangkan dengan tanda titik; intonasi interogatif, yang dalam bahasa tulis dilambangkan dengan tanda tanya; dan intonasi seru, yang dalam bahasa tulis dilambangkan dengan tanda seru.

2) Jenis Kalimat

Kalimat Inti dan Kalimat Non-Inti

Kalimat inti, biasa juga disebut kalimat dasar, adalah kalimat yang dibentuk dari klausa inti yang lengkap bersifat deklaratif, aktif, atau netral, dan afirmatif. Misalnya:

FN + FV + FN + FN : Nenek membacakan kakek komik

Ket : FN=Frase Nominal (diisi sebuah kata nominal); FV=Frase Verbal; FA=Frase Ajektifa; FNum=Frase Numeral; FP=Frase Preposisi.

Kalimat inti dapat diubah menjadi kalimat noninti dengan berbagai proses transformasi:

\section{KALIMATINTI + PROSES TRANSFORMASI = KALIMAT NONINTI}

Ket : Proses Transformasi antara lain transformasi pemasifan, transformasi pengingkaran, transformasi penanyaan, transformasi pemerintahan, transformasi pengonversian, transformasi pelepasan, transformasi penambahan.

(1) Kalimat Tunggal dan Kalimat Majemuk

Kalimat tunggal adalah kalimat yang hanya mempunyai satu klausa. Sedangkan kalimat majemuk adalah kalimat yang terdapat lebih dari satu klausa.

Berkenaan dengan sifat hubungan klausa-klausa dalam kalimat, dibedakan: (1) kalimat majemuk koordinatif/ kalimat majemuk setara yaitu kalimat majemuk yang klausa-klausanya memiliki status yang sama, yang setara, atau yang sederajat. Secara eksplisit dihubungkan dengan konjungsi koordinatif dan biasanya unsur yang sama disenyawakan atau dirapatkan sehingga disebut kalimat majemuk rapatan. (2) Kalimat majemuk subordinatif adalah kalimat majemuk yang hubungan antara klausa-klausanya tidak setara atau sederajat. Klausa yang satu merupakan klausa atasan dan yang lain disebut klausa bawahan. 
Kedua klausa itu dihubungkan dengan konjungsi subordinatif. Proses terbentuknya kalimat ini dapat dilihat dari dua sudut bertentangan. Pertama, dipandang sebagai hasil proses menggabungkan dua buah klausa atau lebih, dimana klausa yang satu dianggap sebagai klausa atasan dan yang lain disebut klausa bawahan. Pandangan kedua, konstruksi kalimat subordinatif dianggap sebagai hasil proses perluasan terhadap salah satu unsur klausanya. (3) Kalimat majemuk kompleks yaitu kalimat majemuk yang terdiri dari tiga klausa atau lebih, dimana ada yang dihubungkan secara koordinatif dan ada pula yang dihubungkan secara subordinatif. Jadi, kalimat ini merupakan campuran dari kalimat majemuk koordinatif dan subordinatif sehingga disebut juga kalimat majemuk campuran.

\section{(2) Kalimat Mayor dan Kalimat Minor}

Kalimat mayor mempunyai klausa lengkap, sekurang-kurangnya ada unsur subjek dan predikat. Sedangkan kalimat minor klausanya tidak lengkap, entah hanya terdiri subjek saja, predikat saja, objek saja, atau keterangan saja; konteksnya bisa berupa konteks kalimat, konteks situasi, atau juga topik pembicaraan.

\section{(3) Kalimat Verbal dan Kalimat non-Verbal}

Kalimat verbal adalah kalimat yang dibentuk dari klausa verbal, atau kalimat yang predikatnya berupa kata atau frase berkategori verba. Sedangkan kalimat nonverbal adalah kalimat yang predikatnya bukan kata atau frase verbal; bisa nominal, ajektifal, adverbial, atau juga numeralia.

Berkenaan dengan banyaknya jenis atau tipe verbal, biasanya dibedakan: (1) kalimat transitif adalah kalimat yang predikatnya berupa verba transitif, yaitu verba yang biasanya diikuti oleh sebuah objek kalau verba tersebut bersifat monotrasitif, dan diikuti oleh dua buah objek kalau verba tersebut bersifat bitransitif. (2) kalimat intransitif adalah kalimat yang predikatnya berupa verba intransitif, yaitu verba yang tidak memiliki objek. (3) kalimat aktif adalah kalimat yang predikatnya kata kerja aktif. Verba aktif biasanya ditandai dengan prefiks me- atau memper- biasanya dipertentangkan degan kalimat pasif yang ditandai dengan prefiks di- atau diper- . Ada juga istilah kalimat aktif anti pasif dan kalimat pasif anti aktif sehubungan dengan adanya sejumlah verba aktif yang tidak dapat dipasifkan dan verba pasif yang tidak dapat dijadikan verba aktif (4) kalimat dinamis adalah kalimat yang predikatnya berupa verba yang secara semantis menyatakan tindakan atau gerakan. (5) kalimat statis adalah kalimat yang predikatnya berupa verba yang secara semantis tidak menyatakan tindakan atau kegiatan. (6) kalimat nonverbal adalah kalimat yang predikatnya bukan verba.

\section{(4) Kalimat Bebas dan Kalimat Terikat}

Kalimat bebas adalah kalimat yang mempunyai potensi untuk menjadi ujaran lengkap, atau dapat memulai sebuah paragraf atau wacana tanpa bantuan kalimat atau konteks lain yang menjelaskannya. Sedangkan kalimat terikat adalah kalimat yang tidak dapat berdiri sendiri sebagai ujaran yang lengkap, atau menjadi pembuka paragraf atau wacana tanpa bantuan konteks. Biasanya kalimat terikat menggunakan salah satu tanda ketergantungan, seperti penanda rangkaian, penunjukan, dan penanda

anaforis. Dari pembicaraan mengenai kalimat terikat, dapat disimpulkan bahwa sebuah kalimat tidak 
harus mempunyai struktur fungsi secara lengkap. Kelengkapan sebuah kalimat serta pemahamannya sangat tergantung pada konteks dan situasinya.

3) Intonasi Kalimat

Intonasi merupakan ciri utama yang membedakan kalimat dari sebuah klausa, sebab bisa dikatakan: kalimat minus intonasi sama dengan klausa; atau kalau dibalik; klausa plus intonasi sama dengan kalimat. Jadi, kalau intonasi dari sebuah kalimat ditanggalkan maka sisanya yang tinggal adalah klausa.

Intonasi dapat diuraikan atas ciri-ciri yang berupa tekanan, tempo, dan nada. Tekanan adalah ciri-ciri suprasegmental yang menyertai bunyi ujaran. Tempo adalah waktu yang diperlukan untuk melafalkan suatu arus ujaran. Nada adalah suprasegmental yang diukur berdasarkan kenyaringan suatu segmen dalam suatu arus ujaran. Dalam bahasa Indonesia dikenal tiga macam nada, yang biasa dilambangkan dengan angka " 1 ", nada sedang dilambangkan dengan angka " 2 ", dan nada tinggi dilambangkan dengan angka "3".

contoh: Bacálah buku itu !

$$
2-32 t / 211 t \#
$$

Ket: $\mathrm{n}=$ naik; $\mathrm{t}=$ turun; tanda - di atas huruf=tekanan

Tekanan yang berbeda menyebabkan intonasinya juga berbeda; akibatnya keseluruhan kalimat itu pun akan berbeda.

4) Modus, Aspek, Kala, Modalitas, Fokus, dan Diatesis

(1) Modus

Modus adalah pengungkapan atau penggambaran suasana psikologis perbuatan menurut tafsiran si pembaca atau sikap si pembicara tentang apa yang diungkapkannya.

Ada beberapa macam modus, antara lain (1) modus indikatif atau modus deklaratif, yaitu modus yang menunjukkan sikap objektif atau netral; (2) modus optatif, yaitu modus yang menunjukkan harapan atau keinginan; (3) modus imperatif, yaitu modus yang menyatakan perintah, larangan, atau tengahan; (4) modus interogatif, yaitu modus yang menyatakan pertanyaan; (5) modus obligatif, yaitu modus yang menyatakan keharusan; (6) modus desideratif, yaitu modus yang menyatakan keinginan atau kemauan; dan (7) modus kondisional, yaitu modus yang menyatakan persyaratan.

Sesungguhnya yang menjadi pembeda antara kalimat deklaratif, interogatif, imperatif, dan interjektif, adalah modus.

(2) Aspek 
Aspek adalah cara untuk memandang pembentukan waktu secara internal di dalam suatu situasi, keadaan, kejadian, atau proses. Dalam berbagai bahasa aspek merupakan kategori gramatikal karena dinyatakan secara morfemis. Dalam bahasa Indonesia aspek dinyatakan tidak secara morfemis melainkan dengan berbagai cara dan alat leksikal. Dalam bahasa Indonesia aspek juga ada yang sudah dinyatakan secara inhern oleh tipe verbanya. Berbagai macam aspek dari berbagai bahasa, antara lain: (1) aspek kontinuatif, yaitu yang menyatakan perbuatan terus berlangsung; (2) aspek inseptif, yaitu yang menyatakan peristiwa atau kejadian yang baru mulai; (3) aspek progresif, yaitu aspek yang menyatakan perbuatan sedang berlangsung; (4) aspek repetitif, yaitu yang menyatakan perbuatan itu terjadi berulang-ulang; (5) aspek perefektif, yaitu yang menyatakan perbuatan sudah selesai; (6) aspek imperfektif, yaitu yang menyatakan perbuatan berlangsung sebentar; dan (8) aspek sesatif, yaitu yang menyatakan perbuatan berakhir.

\section{(3) Kala}

Kala atau tenses adalah informasi dalam kalimat yang menyatakan waktu terjadinya perbuatan, kejadian, tindakan, atau pengalaman yang disebutkan di dalam predikat. Kala ini lazimnya menyatakan waktu sekarang, sudah lampau, dan akan datang. Beberapa bahasa menandai kala itu secara morfemis; artinya, pertanyaan kala itu ditandai dengan bentuk kata tertentu pada verbanya.

Bahasa Indonesia tidak menandai kala secara morfemis, melainkan secara leksikal.

Dalam bahasa Indonesia banyak orang yang mengelirukan konsep kala dengan konsep keterangan waktu sebagai fungsi sintaksis; sehingga mereka mengatakan kala sudah, sedang, dan akan adalah keterangan waktu. Padahal keterangan waktu, dan keterangan lainnya, sebagai fungsi sintaksis memberi keterangan terhadap keseluruhan kalimat. Posisinya pun dapat dipindahkan ke awal kalimat atau ke tempat lain; sedangkan kala terikat pada verbanya atau predikatnya. Penyebab kekeliruan itu barangkali karena kata-kata seperti sudah, sedang, dan akan itu "sejenis" dengan kata-kata kemarin, tadi, dan besok yang menyatakan waktu; dan kata yang terakhir ini memang dapat mengisi fungsi keterangan. Mungkin juga karena dalam tata bahasa tradisional, istilah keterangan digunakan untuk dua macam konsep, yaitu konsep fungsi sintaksis, dan konsep kategori sintaksis.

\section{(4) Modalitas}

Modalitas adalah keterangan dalam kalimat yang menyatakan sikap pembicara terhadap hal yang dibicarakan, yaitu mengenai perbuatan, keadaan, dan peristiwa; atau juga sikap terhadap lawan bicaranya. Sikap ini dapat berupa pernyataan kemungkinan, keinginan, atau juga keizinan. Dalam bahasa Indonesia dan sejumlah bahasa lain, modalitas dinyatakan secara leksikal.

Dalam kepustakaan linguistik dikenal adanya beberapa jenis modalitas; antara lain (1) modalitas intensional, yaitu modalitas yang menyatakan keinginan, harapan, permintaan, atau juga ajakan; (2) modalitas epistemik, yaitu modalitas yang menyatakan kemungkinan, kepastian, dan keharusan; (3) modalitas deontik, yaitu modalitas yang menyatakan keizinan atau keperkeaan; dan (4) modalitas diamik, yaitu modalitas yang menyatakan kemampuan. 
(5) Fokus

Fokus adalah unsur yang menonjolkan bagian kalimat sehingga perhatian pendengar atau pembaca tertuju pada bagian itu. Ada bahasa yang mengungkapkan fokus ini secara morfemis, dengan menggunakan afiks tertentu; tetapi ada pula yang menggunakan cara lain.

Dalam bahasa Indonesia fokus kalimat dapat dilakukan dengan berbagai cara, antara lain: Pertama, dengan memberi tekanan pada bagian kalimat yang difokuskan. Kedua, dengan mengedepankan bagian kalimat yang difokuskan. Ketiga, dengan cara memakai partikel pun, yang, tentang, dan adalah pada bagian kalimat yang difokuskan. Keempat, dengan mengontraskan dua bagian kalimat. Kelima, dengan menggunakan konstruksi posesif anaforis beranteseden.

(6) Diatesis

Diatesis adalah gambaran hubungan antara pelaku atau peserta dalam kalimat dengan perbuatan yang dikemukakan dalam kalimat itu.

Ada beberapa macam diatesis, antara lain, (1) diatesis aktif, yakni jika subjek yang berbuat atau melakukan suatu perbuatan; (2) diatesis pasif, jika subjek berbuat atau melakukan sesuatu terhadap dirinya sendiri; (3) diatesis refleksi, yakni jika subjek berbuat atau melakukan sesuatu terhadap dirinya sendiri; (4) diatesis resiprokal, yakni jika subjek yang terdiri dari dua pihak berbuat tindakan berbalasan; dan (5) diatesis kausatif, yakni jika subjek menjadi penyebab atas terjadinya sesuatu.

\section{Wacana}

1) Pengertian wacana

Wacana adalah satuan bahasa yang lengkap, sehingga dalam hierarki gramatikal merupakan satuan gramatikal tertinggi dan terbesar.

Sebagai satuan bahasa yang lengkap, maka dalam wacana itu berarti terdapat konsep, gagasan, pikiran, atau ide yang utuh, yang bisa dipahami oleh pembaca (dalam wacana tulis) atau pendengar (dalam wacana lisan) tanpa keraguan apapun. Sebagai satuan gramatikal tertinggi atau terbesar, wacana dibentuk dari kalimat-kalimat yang memenuhi persyaratan gramatikal, dan persyaratan kewacanaan lainnya. Persyaratan gramatikal dapat dipenuhi kalau dalam wacana itu sudah terbina kekohesifan, yaitu adanya keserasian hubungan antara unsur-unsur yang ada dalam wacana sehingga isi wacana apik dan benar.

\section{2) Alat Wacana}

Alat-alat gramatikal yang dapat digunakan untuk membuat sebuah wacana menjadi kohesif, antara lain: Pertama, konjungsi, yakni alat untuk menghubung-hubungkan bagian-bagian kalimat; atau menghubungkan paragraf dengan paragraf. Kedua, menggunakan kata ganti dia, nya, mereka, ini, dan itu sebagai rujukan anaforis sehingga bagian kalimat yang sama tidak perlu diulang melainkan 
menggunakan kata ganti. Ketiga, menggunakan elipsis, yaitu penghilangan bagian kalimat yang sama yang terdapat kalimat yang lain.

Selain dengan upaya gramatikal, sebuah wacana yang kohesif dan koheren dapat juga dibuat dengan bantuan berbagai aspek semantik, antara lain: Pertama, menggunakan hubungan pertentangan pada kedua bagian kalimat yang terdapat dalam wacana itu. Kedua, menggunakan hubungan generik spesifik; atau sebaliknya spesifik - generik. Ketiga, menggunakan hubungan perbandingan antara isi kedua bagian kalimat; atau isi antara dua buah kalimat dalam satu wacana. Keempat, menggunakan hubungan sebab - akibat di antara isi kedua bagian kalimat; atau isi antara dua buah kalimat dalam satu wacana. Kelima, menggunakan hubungan tujuan di dalam isi sebuah wacana. Keenam, menggunakan hubungan rujukan yang sama pada dua bagian kalimat atau pada dua kalimat dalam satu wacana.

\section{3) Jenis Wacana}

Berkenaan dengan sasarannya, yaitu bahasa lisan atau bahasa tulis, dilihat adanya wacana lisan dan wacana tulis.

Dilihat dari penggunaan bahasa apakah dalam bentuk uraian ataukah bentuk puitik dibagi wacana prosa dan wacana puisi. Selanjutnya, wacana prosa, dilihat dari penyampaian isinya dibedakan menjadi wacana narasi, wacana eksposisi, wacana persuasi dan wacana argumentasi.

\section{4) Subsatuan Wacana}

Dalam wacana berupa karangan ilmiah, dibangun oleh subsatuan atau sub-subsatuan wacana yang disebut bab, subbab, paragraf, atau juga subparagraf. Namun, dalam wacana -wacana singkat subsubsatuan wacana tidak ada.

\section{DAFTAR PUSTAKA}

Bressler, Charles E. 1999. Literary Criticism : An Introduction to Theory and Practice. Second Edition. New Jersey: Prentice Hall, Upper Saddle River.

Child, Peter and Roger Fowler. 2006. The Routledge Dictionary of Literary Terms. London and New York: Routledge.

Darwis, Muhammad. 2002. Pola-Pola Gramatikal dalam Puisi Indonesia. Dalam Jurnal Masyarakat Linguistik Indonesia edisi Tahun 20, Nomor 1, Februari 2002.

Davies, Alan and Catherine Elder (Ed). 2006. The Handbook of Applied Linguistics. Australia: Blackwell Publishing.

Depdiknas. 2005. Kamus Besar Bahasa Indonesia (edisi 3). Jakarta: Balai Pustaka.

Kridalaksana, Harimurti. 2001. Kamus Linguistik (edisi IV). Jakarta: PT Gramedia Pustaka Utama.

Mikics, David. 2007. A New Handbook of Literary Term. London: Yale University Press. 
Simpson, Paul. 2004. Stylistics : A Resource Book for Student. New York: Roudledge.

Starcke, Bettina Fischer. 2010. Corpus Linguistics in Literary Analysis. New York: Continuum nternationa Publishing Group.

Lafamane, F. (2020). Tata Bahasa Fungsional (functional Grammar).

Lafamane, F. (2020). Fenomena Penggunaan Bahasa Daerah di Kalangan Remaja.

Amanto, B. S., Umanailo, M. C. B., Wulandari, R. S., Taufik, T., \& Susiati, S. (2019). Local Consumption Diversification. Int. J. Sci. Technol. Res, 8(8), 1865-1869.

Amri, M., Tahir, S. Z. A. B., \& Ahmad, S. (2017). The Implementation of Islamic Teaching in Multiculturalism Society: A Case Study at Pesantren Schools in Indonesia. Asian Social Science, 13(6), 125.

Andini, K. NILAI BUDAYA SUKU BAJO SAMPELA DALAM FILM THE MIRROR NEVER LIES KARYA KAMILA ANDINI.

ARYANA, A. PERBANDINGAN GAYA BAHASA DALAM NOVEL ATHEIS KARYA ACHDIAT KARTA MIHARDJA DAN NOVEL TELEGRAM KARYA PUTU WIJAYA: TINJAUAN STILISTIKA.

Crystal, David. 2000. New Perspectives of Language Study 1 : Stylistics. University of Reading: Department of Linguistics Science.

Djamudi, N. L., Nurlaela, M., Nazar, A., Nuryadin, C., Musywirah, I., \& Sari, H. (2019, October). Alternative social environment policy through educational values in Kafi'a's customary speech to the kaledupa community of Wakatobi Island, Indonesia. In IOP Conference Series: Earth and Environmental Science (Vol. 343, No. 1, p. 012118). IOP Publishing..

Indonesia, K. K. D. B. Morfologi Bahasa Indonesia.

Iye, R., \& Susiati, S. (2018). NILAI EDUKATIF DALAM NOVEL SEBAIT CINTA DI BAWAH LANGIT KAIRO KARYA MAHMUD JAUHARI ALI (Educative Values in Sebait Cinta di Bawah Langit Kairo by Mahmud Jauhari Ali). Sirok Bastra, 6(2), 185-191.

Iye, R. (2018). Tuturan emosi mahasiswa kota baubau dalam ranah demonstrasi.

Iye, R., Susiati, S., \& Karim, K. (2020). Citra Perempuan dalam Iklan Sabun Shinzui. Sang Pencerah: Jurnal IImiah Universitas Muhammadiyah Buton, 6(1), 1-7.

Karim, K., Maknun, T., \& Abbas, A. (2019). Praanggapan Dalam Pamflet Sosialisasi Pelestarian Lingkungan Di Kabupaten Wakatobi. Jurnal IImu Budaya, 7(2), 241-247.

Lafamane, F. (2020). Tata Bahasa Sistemik Fungsional (Suatu Pandangan).

Lafamane, F. (2020). Perkembangan Teori Sastra (suatu Pengantar). OSF Preprints. July, 25. 
Mansyur, F. A., \& Suherman, L. A. (2020). The Function of Proverbs as Educational Media: Anthropological Linguistics on Wolio Proverbs. ELS Journal on Interdisciplinary Studies in Humanities, 3(2), 271-286.

Rahayaan, I., Azwan, A., \& Bugis, R. (2016). The Students' Writing Ability through Cooperative Script Method. Jurnal Retemena, 2(2).

Salamun, T. (2018). DEIKSIS PERSONA BAHASA INDONESIA DIALEK AMBON [Personal Deixes of Indonesian Leanguage With Ambonese Dialect]. Totobuang, 5, 325-339.

Salamun, T. (2018). RELASI KEKERABATAN BAHASA HITU, WAKAL, MORELA, MAMALA, DAN HILA DI PROVINSI MALUKU [The Family Relationship Language Hitu, Wakal, Morela, Mamala, and Hila in Maluku Province].

Suherman, L. A. (2018). The Analysis of Metaphorical Domain on English "Stab Verb" in Corpora. ELS Journal on Interdisciplinary Studies in Humanities, 1(1), 52-58.

Suherman, L. O. A., Salam, S., Mursanto, D., Efendi, A., Bahar, S. B., \& Kanna, T. (2019, October). The effect of open-air curing on compressive strength of geopolymer mortar containing laterite soil and slaked lime. In IOP Conference Series: Earth and Environmental Science (Vol. 343, No. 1, p. 012133). IOP Publishing.

Susiati, S., \& Iye, R. (2018). Kajian Geografi Bahasa dan Dialek di Sulawesi Tenggara: Analisis Dialektometri. Gramatika: Jurnal IImiah Kebahasaan dan Kesastraan, 6(2), 137-151.

Susiati, S. Dialektometri Segitiga: Hubungan Kekerabatan Bahasa Di Sulawesi Tenggara (Bahasa Wakatobi, Bahasa Cia-Cia, Bahasa Pancana, Bahasa Kioko, Bahasa Tolaki).

Susiati, S., lye, R., \& Suherman, L. O. A. (2019). Hot Potatoes Multimedia Applications in Evaluation of Indonesian Learning In SMP Students in Buru District. ELS Journal on Interdisciplinary Studies in Humanities, 2(4), 556-570.

Susiati, S. (2018). Homonim bahasa kepulauan tukang besi dialek kaledupa di kabupaten wakatobi [the homonymon of tukang besi island languange in kaledupa dialect at wakatobi regency]. Totobuang, 6 (1), $109,123$.

Susiati, S. (2020). Emosi Verbal Suku Bajo Sampela.

Susiati, S. (2020). Fenomena Tuturan Emosi Verbal Bahasa Indonesia Suku Bajo Sampela.

Susiati, S. (2020). Nilai Budaya Suku Bajo Sampela Dalam Film The Mirror Never Lies Karya Kamila Andini.

Susiati, S. (2020). Konsep Pertentangan Dalam Film" Aisyah Biarkan Kami Bersaudara" Karya Herwin Novianto.

Susiati, S. (2020). Strategi AMBT untuk Meningkatkan Kemampuan Membaca Pemahaman Interpretatif Siswa Kelas IV SD Negeri 3 Namlea Kabupaten Buru. 
Susiati, S. (2020). Fungsi Konatif Pada Iklan Mesin Cuci Hole-Less Tub Dari Sharp: Analisis Wacana Kritis.

Susiati, S. (2020). GAYA BAHASA SECARA UMUM DAN GAYA BAHASA PEMBUNGKUS PIKIRAN.

Susiati, S. (2020). The Concept Of Togetherness In The Films" Aisyah Biarkan Kami Bersaudara" By Herwin Novianto.

Susiati, S. (2020). Konsep Kebersamaan Dalam Film" Aisyah Biarkan Kami Bersaudara" Karya Herwin Novianto.

Susiati, S. (2020). Teori dan Aliran Linguistik: Tata Bahasa Generatif.

Susiati, S. (2020). Metode Pembelajaran Bahasa Indonesia: Sosiodrama.

Susiati, S. (2020). Rekontruksi Internal Bahasa Bugis dan Bahasa Makassar: Linguistik Komparatif.

Susiati, S. Bahan Ajar: Psikolinguistik.

Susiati, S. (2020). PENTINGNYA MELESTARIKAN BAHASA DAERAH.

Susiati, S. (2020). Morfologi Kelas Kata Dalam Bahasa Indonesia.

Susiati, S. (2020). Semantik: Teori Semantik, Relasi Makna, Marked, Dan Unmarked.

Susiati, Y. T. Risman Iye. A. Kesantunan Imperatif Bahasa Indonesia Suku Bajo Sampela: Balai Pembinaan dan Pengembangan Bahasa. 2018. Kongres Bahasa Indonesia (No. 12, pp. 1-6). Report.

Susiati, S. (2020). Internal Recontruction Bugis Language and Makassar Language.

Susiati, S. (2020). Kesantunan Imperatif Bahasa Melayu Ambon.

Susiati, S. (2020). Nilai Budaya Suku Bajo Sampela Dalam Film The Mirror Never Lies Karya Kamila Andini.

Susiati, S. (2020). Pengaplikasian Multimedia Hot Potatoes Dalam Evaluasi Pembelajaran Bahasa Indonesia Pada Siswa SMP Negeri 9 Buru.

Susiati, S., \& lye, R. (2018). Kajian Geografi Bahasa dan Dialek di Sulawesi Tenggara: Analisis Dialektometri. Gramatika: Jurnal IImiah Kebahasaan dan Kesastraan. 6 (2), 137-151.

Susiati, S. (2020). Kaidah Fonologi Bahasa Indonesia.

Susiati, S. (2020). Wujud Morfologi Bahasa Indonesia.

Susiati, S. (2020). Makian Bahasa Wakatobi Dialek Kaledupa.

Susiati, S. (2020). Eksistensi Manusia Dalam Film" Aisyah Biarkan Kami Bersaudara" Karya Herwin Novianto.

SUsiati, S. NILAI BUDAYA SUKU BAJO SAMPELA DALAM FILM THE MIRROR NEVER LIES. 
Susiati, S. (2020). Konsep Keterasingan Dalam Film" Aisyah Biarkan Kami Bersaudara" Karya Herwin Novianto.

Susiati, S. (2020). Concept Of Conflict In The Films "AISYAH BIARKAN KAMI BERSAUDARA" By Herwin Novianto.

Susiati, S. (2020). Embrio Nasionalisme Dalam Bahasa dan Sastra.

Susiati, S. PERWUJUDAN SIMILE OLEH MERARI SIREGAR DALAM NOVEL AZAB DAN SENGSARA.

Susiati, S. (2020). Nilai Pembentuk Karakter Masyarakat Wakatobi Melalui Kabhanti Wa Leja.

Tenriawali, A. Y. (2018). Representasi korban kekerasan dalam teks berita daring tribun timur: analisis wacana kritis [the representation victims of violence in tribun timur online news text: critical discourse analysis]. TOTOBUANG, 6 (1), 1, 15.

Susiati, S. (2020). Gaya Bahasa Secara Umum Dan Gaya Bahasa Pembungkus Pikiran: Stilistika.

Susiati, S. (2020). Tuturan Kesantunan Imperatif Bahasa Indonesia Suku Bajo Sampela.

Yusdianti, A. (2020). THE REPRESENTATION VICTIMS OF VIOLENCE IN TRIBUN TIMUR ONLINE NEWS TEXT: CRITICAL DISCOURSE ANALYSIS.

Verdonk, Peter. 2002. Stylistics. New York: Oxford University Press.

Wellek, Rene dan Austin Warren. 1989. Teori Kesusastraan. Diterjemahkan oleh Melani Budianta. Jakarta: Gramedia.

Widdowson, H.G. 1997. Stilistika dan Pengajaran Sastra. Diterjemahkan oleh Sudijah. Surabaya: Airlangga University Press.

Wynne, Martin. 2005. Stylistics : Corpus Approaches. Oxford: Oxford University.

Yunus, Umar. 1989. Stilistika; Suatu Pengantar. Kuala Lumpur : Dewan Bahasa dan Pustaka.

Zhang, Zhiqin. 2010. The Interpretation of a Novel by Hemingway in Term of Literary.

Zulfahnur, dkk. 1996. Teori Sastra. Jakarta: Depdikbud 